\title{
Regeneration of Araucaria angustifolia in pine plantations in the South of Brazil - a silvicultural approach
}

\author{
Regeneração de Araucaria angustifolia em plantações de Pinus no Sul do \\ Brasil - uma abordagem silvicultural
}

Juergen Huss ${ }^{1}$ (D), Mário Dobner Jr. ${ }^{2}$ (1), Crysttian Arantes Paixão ${ }^{2}$ (1) , Alexandre ten Caten² (D), Alexandre Siminski ${ }^{2}$

${ }^{1}$ Freiburg University. Freiburg, Baden-Württemberg, Germany

2Universidade Federal de Santa Catarina - UFSC, Curitiba, SC, Brasil

How to cite: Huss, J., Dobner Jr., M., Paixão, C. A., ten Caten, A., \& Siminski, A. (2020). Regeneration of Araucaria angustifolia in pine plantations in the South of Brazil - a silvicultural approach. Scientia Forestalis, 48(127), e3265. https://doi.org/10.18671/scifor.v48n127.16

\begin{abstract}
The formerly wide-spread Araucaria angustifolia forests in S-Brazil have been cut during the whole of the $20^{\text {th }}$ century and were converted into pastures, agricultural fields and forest plantations of pine and eucalyptus species. Araucarias only remained in small woodlots, groups or as single trees. Therefore, they were legally protected. The objectives of this study were to investigate the distribution of Araucaria seedlings in pine stands in order to consider whether Araucaria seedlings can be used for transforming pine plantations into mixed stands. Seedlings and saplings were detected in loblolly pine (Pinus taeda) plantations of a medium sized enterprise by means of a systematic large-scale inventory. Although the seedlings and saplings were heterogeneously distributed, they could be used for mixtures of up to one third of the area. The numbers of Araucaria seedlings and saplings were highly correlated with the distance to secondary forests containing old Araucarias as seed-bearing trees, with the age and also the number of thinnings of the sheltering pines. Nevertheless, the dataset was zero inflated, being the basal area of the pine stands a significant factor in this context. From the ecological point of view, it would be advisable to reconsider the strict Araucaria protection rules in order to encourage land owners to make use of the natural regrowth for mixtures with pines. However, this would also need a revision of the management standards for pine plantations, including longer rotation periods and early as well as intensive thinnings.
\end{abstract}

Keywords: Araucaria regrowth; Distribution of Araucaria seeds; Natural regeneration; Araucaria as a mixture tree for pine plantations.

\section{Resumo}

A floresta de Araucaria angustifolia que era amplamente distribuída no sul do Brasil foi intensamente explorada durante todo o século 20, tendo sido em grande parte convertida em pastagens, solos agricultáveis e plantações florestais com espécies de Pinus e Eucalyptus. Araucárias somente remanesceram em pequenos fragmentos, em pequenos grupos ou mesmo como árvores isoladas. Por isso, a espécie foi legalmente protegida. Entretanto, indivíduos regenerantes foram detectados em plantações de Pinus taeda de numa empresa florestal de médio porte por meio de um inventário sistemático de grande escala. Embora a regeneração estivesse distribuída de forma heterogênea, esta poderia ser utilizada para a formação de povoamentos mistos em até um terço da área estudada. 0 número de araucárias regenerantes apresentou alta correlação com a distância até o fragmento de floresta nativa mais próximo, esta contendo árvores adultas de araucária como porta-sementes, com a

Financial support: Eva Mayr-Stihl-Stiftung partially supported data collection in Brazil.

Conflict of interest: Nothing to declare.

Corresponding author: mario.dobner@ufsc.br

Received: 30 January 2019.

Accepted: 12 September 2019.

Editor: Francides Gomes da Silva Júnior.

(i) This is an Open Access article distributed under the terms of the Creative Commons Attribution License, which permits unrestricted use, distribution, and reproduction in any medium, provided the original work is properly cited. 
idade e com o número de desbastes do povoamento de Pinus. Contudo, a base de dados avaliada estava zero inflacionada, sendo a área basal dos povoamentos de Pinus um importante fator neste contexto. De uma perspectiva ecológica, é recomendável reconsiderar as rigorosas regras de proteção da araucária de forma a encorajar os proprietários rurais a fazerem uso da regeneração natural para a formação de povoamentos mistos com Pinus. Entretanto, isto demandaria também uma revisão dos padrões de manejo para as plantações de Pinus, incluindo rotações mais longas e desbastes intensos e precoces.

Palavras-chave: Dispersão de sementes de araucária; Regeneração natural; Araucária para formação de povoamentos mistos com Pinus.

\section{INTRODUCTION}

\section{Problem statement}

Araucaria angustifolia (Bertol.) Kuntze, the Brazilian or Paraná pine, is the most important indigenous conifer of Brazil. Around 1900 it covered an area of roughly $200,000 \mathrm{~km}^{2}$ (Lima \& Capobianco, 1997). 80\% were distributed in the southern Brazilian states of Paraná, Santa Catarina and Rio Grande do Sul. Its timber is of high value and can be used for many purposes, especially sawn timber for construction and furniture. Cuttings started around 1880 and a noteworthy sawmilling industry developed in southern Brazil. For roughly 100 years its timber market relied widely on the supply from the native forests with dominating Araucaria until they were mostly exhausted. Apart from timber exploitation, the clearing of these forests to reclaim grazing ground and agricultural fields was also an important issue.

At the end of the $20^{\text {th }}$ century less than $3 \%$ of primary Araucaria forests remained (lob \& Vieira, 2008; IUCN Red List of Threatened Species, 2017). As a consequence of the overexploitation, Araucaria angustifolia was defined as being a highly endangered species (IUCN Red List of Threatened Species, 2017). Since 2001 log exports are officially banned (Brasil, 2001), and since 2006 it is even prohibited to harvest any naturally grown Araucaria trees (Brasil, 2006). Only in-line planted ones can be used economically.

Despite of these large-scale deforestations, Araucarias have survived in fragmented native secondary forests as well as alongside fields and meadows as single trees, sometimes in groups, woodlots or smaller forests (Figure 1).

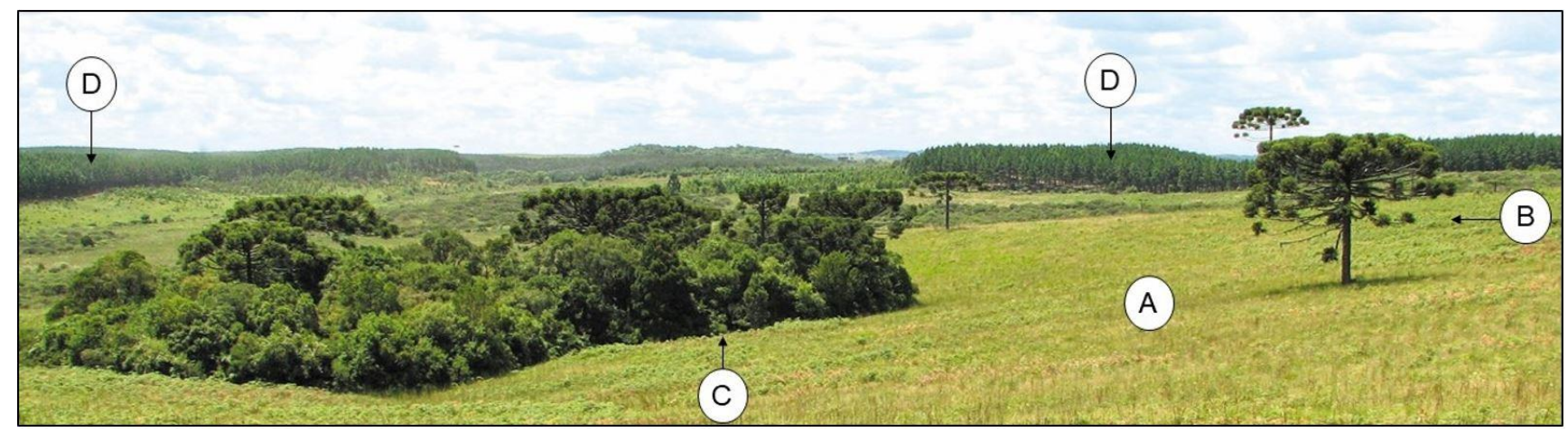

Figure 1. A typical landscape in Santa Catarina with (A) cleared grasslands which are used as pasture or annual cropping, (B) leftover single Araucarias, (C) secondary native forest and (D) loblolly pine plantations.

Moreover, in many places around seed-bearing mother-trees Araucaria regenerates freely, in spite of the fact that Araucaria seeds are eaten by many animals and intensively collected by the local population for food (Pereira \& Ganade, 2008; Reis et al., 2014; Adan et al., 2016), which make it one important non-wood-forest-product of the Atlantic Forest domain (Instituto Brasileiro de Geografia e Estatística, 2018).

According to data from the state forest inventory of Santa Catarina, $21 \%$ of the Araucaria forests remain as secondary remnants (Vibrans et al., 2012, 2013). 
In the long run Araucaria might offer an opportunity to be used as a mixture tree, especially in the vast pine and eucalypt plantations which have been afforested in southern Brazil during the last decades. This could be a feasible approach to help conserving Araucaria angustifolia due to its use. Therefore, it seems to be necessary to test and develop forms of mixtures which are less imperilled and might be applied in practice after the actual and arguable legal restrictions have been reviewed.

Some projections in this direction have been started by the authors in southern Brazil. Especially inventories of naturally regenerated Araucaria seedlings in loblolly pine (Pinus taeda L.) stands have been carried out in order to study their potential for the management of mixed stands in future. In this article we show that young Araucarias develop coincidentally in pine plantations and discuss the implications which they may cause.

\section{Araucaria regeneration in southern Brazil}

Araucaria is a prevalent attribute of the Mixed Ombrophilous Forest and was the landscape determining species on the highlands of southern Brazil within the Atlantic Forest biome. The current typical landscape in this plateau area is formed by a mosaic of former Araucaria-dominated forests and grasslands. The persistence of the grassland vegetation, however, under the humid, specific forest climate with favourable soil conditions is only possible because of anthropogenic disturbances (fire and cattle) (Overbeck et al., 2007).

Araucaria angustifolia is a dioecious species which produces seeds in 2-3 years cycles (Mantovani et al., 2004). The relatively heavy seeds (5-7 g each) are spread under the crowns of the female specimens and need animals for their distribution.

Araucarias large seeds contain vast energy reserves that permit seedlings to grow in low light environments and don't need to compete for resources (Ganade et al., 2011). This seems to be the background that it can grow as well in broadleaf-dominated secondary forests as under the shelter of mono-species plantations such as pine stands.

During the initial stage of growth, Araucaria is shade-tolerant, but it will only become a dominant tree if space in the canopy is opened (Soares, 1979; Seitz, 1986; Dillenburg et al., 2009). Thus, it is currently classified as a long-living pioneer (Dillenburg et al., 2009).

As the seeds are nutritious and tasty, a major number of animals feed on them. The most important predators of Araucaria seeds are small rodents and squirrels (Sciurus ingram) as well as agoutis (Dasyprocta azarae), which, however, use to devour most of the seeds and carry some of them to near storage places. Only rarely some left-over seeds then get the opportunity to germinate. Mice carry seeds only 2-7 m away and other rodents to $\leq 26 \mathrm{~m}$ far from the seed-bearing mother trees (lob \& Vieira, 2008; Brum et al., 2010).

Bittencourt \& Sebbenn (2007), however, found seedlings in distances between 0,35 and $281 \mathrm{~m} ; 38 \%$ of them up to $60 \mathrm{~m}$ far from the mother trees and $83 \%$ up to $160 \mathrm{~m}$ away. The main seed dispersers are presumed to be birds, but possibly also squirrels. Especially the ,azure-jay' (Cyanocorax caeruleus) is regarded as being primarily responsible for Araucaria regeneration in natural habitats due to hiding and storing of seeds for later consumption (Bordignon \& Monteiro-Filho, 2000; lob \& Vieira, 2008; Vieira \& lob, 2009). Another less wellknown jay species, the ,pileated jay' (Cyanocorax chrysops) has been recently observed burying seeds, probably also for later consumption (Anjos \& Shibatta, 2010; Schüssler, 2014).

There is little information about the distribution and magnitude of naturally dispersed Araucaria regrowth in plantations and the possible relevance of these young plants for especially converting pine-monocultures into mixed stands.

\section{Hypotheses and objectives}

The hypothesis was formulated that Araucaria seeds are vastly distributed in pine plantations and that they can be used for the future management of forests, provided seedbearing old Araucarias still exist. 
The objectives of this study were, therefore, to gain reliable information about the distribution of Araucaria seedlings in pine stands of a representative forest enterprise in the southern Brazilian highlands.

Moreover, some considerations should be raised whether Araucaria seedlings can be used for transforming pine plantations into mixed stands. Although at moment there is little chance to put this idea into practice because of the mentioned legal restrictions, this may change in due time. By then suggestions and recommendations for the silvicultural management of these forest types should be available and appropriate for transfer into the practice.

\section{MATERIAL AND METHODS}

\section{Study area}

A large-scale inventory has been carried out in a medium sized forest enterprise located in the highlands of the state of Santa Catarina, near the regional centre Lages. There the former indigenous Araucaria-dominated forests had been cleared off many decades ago and converted either into agricultural fields or into pasture land. Since the 1980ies most of them have been afforested mainly with loblolly pines.

However, secondary broadleaf forests and some primary forests remained alongside the streams. Varying numbers of left-over Araucarias still exist in deeply indented valleys, but also in fields and meadows (compare Plate 1). This mixture of remaining secondary forests and plantations created a great variety of landscape forms, which is characteristic of this region.

The site conditions are generally very favourable for forest growth because of the following features: Altitude: $900-1,100 \mathrm{~m}$ asl; climate: humid-subtropical; rainfall: 1,800 mm per year, evenly distributed, thus excluding water-deficit periods; temperature: $16{ }^{\circ} \mathrm{C}$, mild; frosts: 2-30 days per year. Length of vegetation period: almost the whole year round; soil: predominantly nitosols and cambisols of volcanic origin with basalt and diabasic as parental material (Dortzbach et al., 2016); regional topography: rolling to strongly rolling.

\section{Large-scale inventory}

A large-scale inventory of Araucaria regeneration under pine stands was conducted. A total of 519 circular plots of $500 \mathrm{~m}^{2}$ (radius $=12.62 \mathrm{~m}$ ) were sampled during May-Aug 2016 . They were systematically distributed within single stands of $\sim 3,000$ ha in total of loblolly pine plantations with an age of at least 6 years. Thus, there was 1 plot every 5.8 ha. The pine stands were usually in close contact with surrounding or adjacent secondary forests. These in general included old Araucarias which could possibly have acted as seed sources.

Araucaria regrowth within the plots was counted and classified in two groups related to total height: < $3 \mathrm{~m}$, young seedlings; $\geq 3 \mathrm{~m}$, fully established saplings. Later, however, analyses regarded only the presence or absence of Araucaria regrowth.

The Araucaria seedlings and saplings were also evaluated in relation to the following characteristics and factors of possible influence (number or range of values in parentheses): Age of the pine stands (6-34 years); height of pines (8-39 m); number of thinning (0-5 interventions); number of pine trees (60-1,820 trees ha $\left.{ }^{-1}\right)$; basal area of the pine stands (7-55 $\mathrm{m}^{2} \mathrm{ha}^{-1}$ ); plot distance to the closest native forest fragment (a straight line, 2-400 m).

Thinnings within these loblolly pine stands are consistently carried out when the basal area reached 45-50 $\mathrm{m}^{2} \mathrm{ha}^{-1}$, being reduced to no less than 25-30 $\mathrm{m}^{2} \mathrm{ha}^{-1}$.

Spatial data were obtained through the software QGIS version Las Palmas 2.18.5 (QGIS Development Team, 2017). A sample of the landscape, together with the plots is given in Figure 2. 


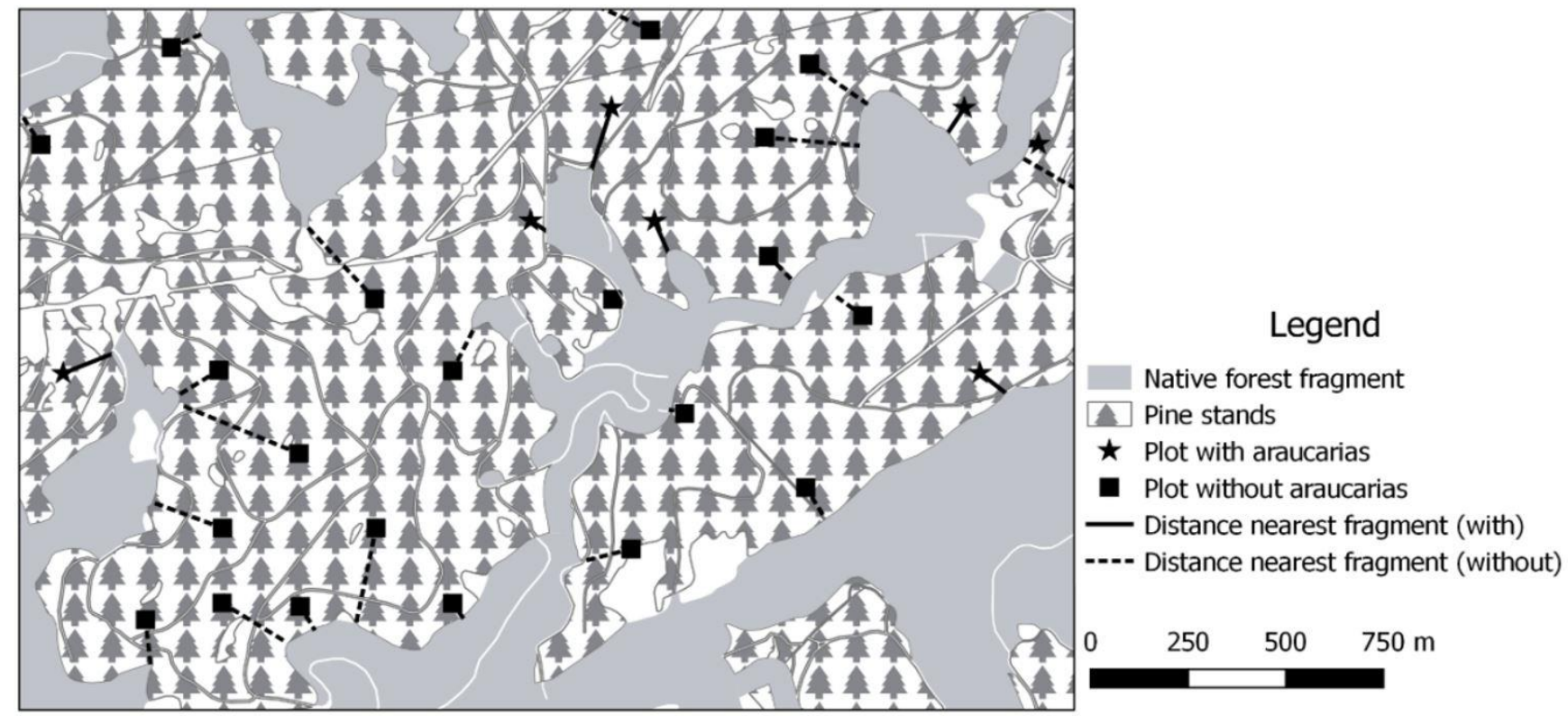

Figure 2: Inventory plots with (stars) and without (squares) Araucaria regrowth. Araucaria regrowth is given together with the straight-line distance between the closest native forest fragment and the pine plot.

Straight line distances between the closest native forest fragments and the pine plots were exported in table format for subsequent statistical analyses.

Regression analyses were carried out with ' $R$ ' (R Core Team, 2017). Different models were tested to explain the total amount of Araucaria regrowth, from which the ones for zero inflated data resulted in the best fitting. Some of the zeros belong also to the counting part since there are two sources of zeros: one of them is natural and expected, the other one is inflated (Beaujean \& Morgan, 2016). Models were selected via AIC score.

\section{RESULTS AND DISCUSSION}

\section{Distribution of Araucaria regrowth in the plots}

The distribution of Araucaria regrowth was extremely heterogeneous. The probability that different numbers of Araucaria seedlings occur under pine stands, obtained with help of the fitted model is given in Figure 3.

It shows that the number of seedlings and saplings per sample plot - converted into plants per hectare - varied immensely. There was an almost equal number of plots with a wide range of 20-300 young Araucaria ha ${ }^{-1}$, altogether in roughly 1/3 of the plots. Even a maximum of 440 young Araucarias ha ${ }^{-1}$ was detected underlining the great differences in the regeneration observed in the field. Complementarily, Figure 3 also illustrates that roughly 2/3 of all plots did not contain young Araucarias at all.

Thus, in $\sim 35 \%$ of the pine stands there is some probability of encountering Araucaria regrowth. From a silvicultural point of view, and according to the densities, $27 \%$ of the pine plantation area has a potential for a pine-Araucaria mixture $\left(<100\right.$ seedlings ha $\left.{ }^{-1}\right)$, and $8 \%$ could be managed as a pure Araucaria stand $\left(\geq 100\right.$ seedlings ha- $\left.{ }^{-1}\right)$. Thus, roughly $1 / 3$ of the pine stands could be managed taking Araucaria into consideration to some extent. 


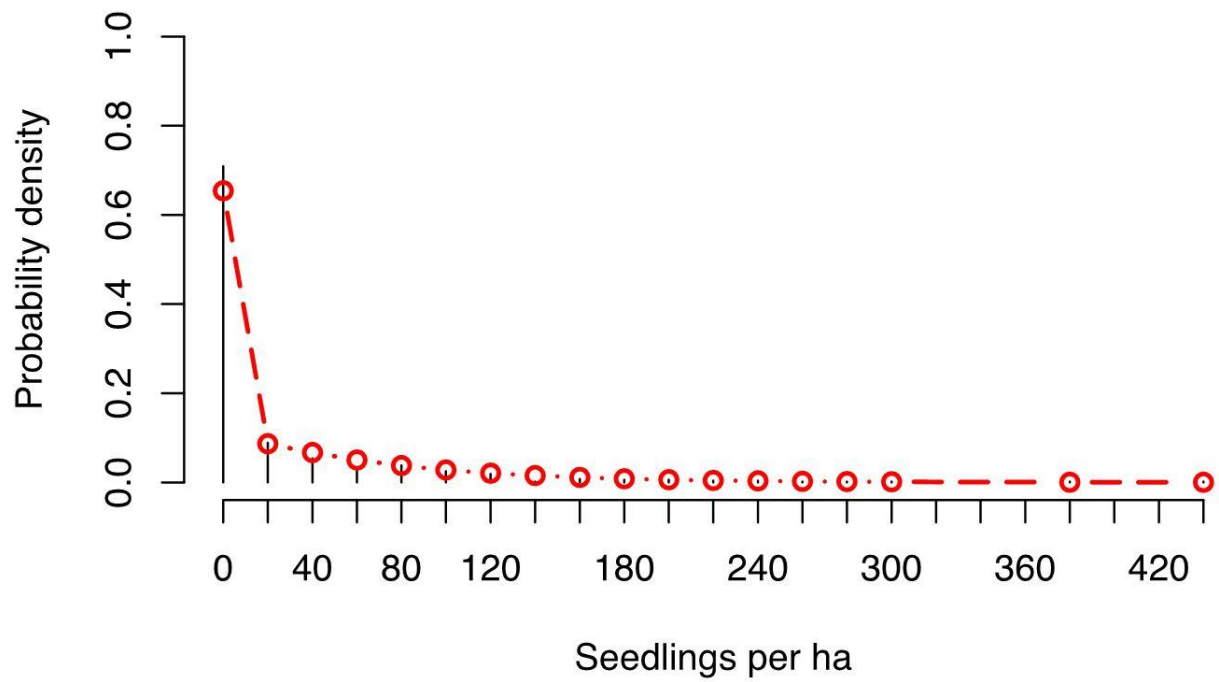

Figure 3: Probability of different numbers of Araucaria seedlings occurring under pine stands. Observed (bars) and estimated (red dots linked by red dashed lines) values.

The data shown in Figure 3 are evidently zero-inflated, i.e. there is an excessive number of zeros in the outcome variable. Zero-inflated datasets can be analysed by mixing two models and two distributions - with a first regression the non-occurrence (predicts the zeros) is examined; with the second one it is found out how frequently the behaviour occurred (Beaujean \& Morgan, 2016). Several analyses were carried out and, for the analysed data; the best fitting was obtained by a negative binomial model for both the counting part prediction and the zero-inflated part of the data (Table 1).

Table 1: Parameters of the zero-inflated negative binomial model adjusted for Araucaria seedlings counting dataset $(n=519)$. All parameters were obtained with a $p$-value $<0.01$.

\begin{tabular}{ccccc}
\hline Variable & $\begin{array}{c}\text { Parameter } \\
\text { estimate }\end{array}$ & $\mathbf{e}^{\text {parameter }}$ & $\mathbf{2 . 5 \%}$ & $\mathbf{9 7 . 5 \%}$ \\
\hline count - Intercept & 1.728 & 5.631 & 2.770 & 15.963 \\
count - Distance to secondary forest & -0.011 & 0.988 & 0.984 & 0.991 \\
count - Number of thinnings & -0.568 & 0.566 & 0.379 & 0.776 \\
count - Age of pine forests & 0.097 & 1.101 & 1.034 & 1.174 \\
zero - Intercept & 1.890 & 6.620 & 1.843 & 14.441 \\
zero - Basal area & -0.047 & 0.953 & 0.928 & 0.980 \\
Log-likelihood & & -605.3 & & \\
Model df & & 7 & & \\
AlC & & $1,224.7$ & & \\
\hline
\end{tabular}

Knowing the exact location of each sampling plot, as well as the characteristics of the pine stands across the landscape, allowed the evaluation of the quoted factors which might have affected the natural regeneration of Araucaria. Those significantly related to the probability density of Araucaria seedlings, positively (age) and negatively (number of thinnings and distance to secondary forests), as well as the zero-inflated part of the data (basal area, negatively correlated) will be presented in the sequence.

\section{Factors influencing the probability density of Araucaria regrowth}

Three factors had significant influence as driving factors on the probability density of seedlings and saplings in the study area, as shown in Table 1 . They will be separately presented in the following sections. The intercept of the counting part of model indicates that the average 
density was $\sim 5.6$ Araucaria seedlings ha ${ }^{-1}$ (95\% confidence interval between 2.8-16.0). The interpretation of each model parameters was individually regarded, keeping all others as fixed values.

\section{Distance to the native secondary forests as a driving factor}

It is shown in Figure 4a.

(a)

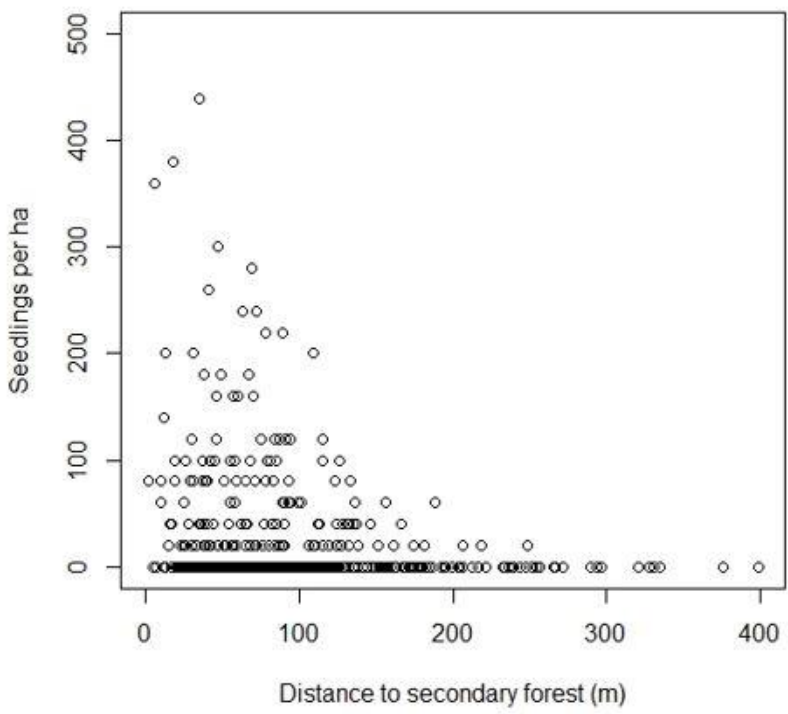

(c)

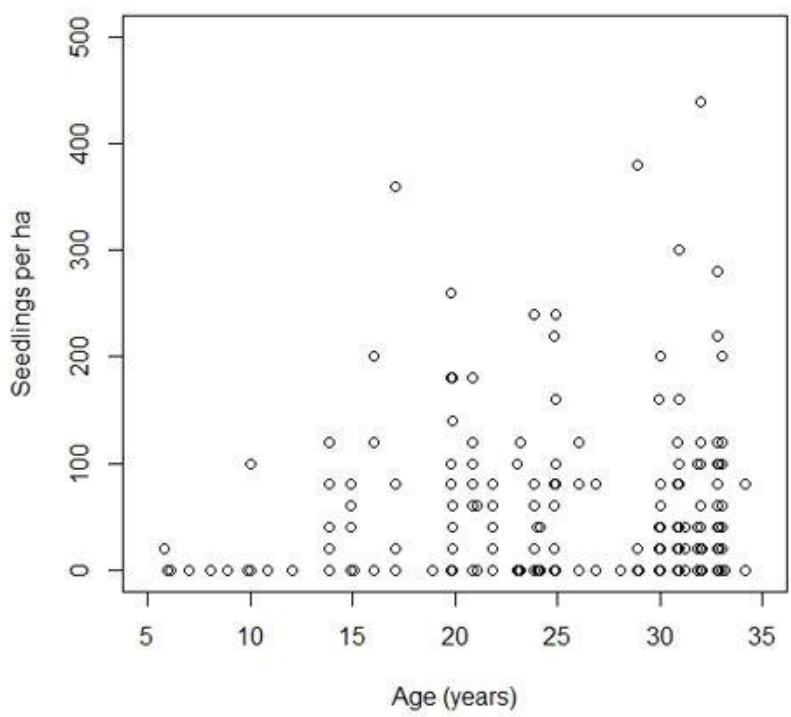

(b)

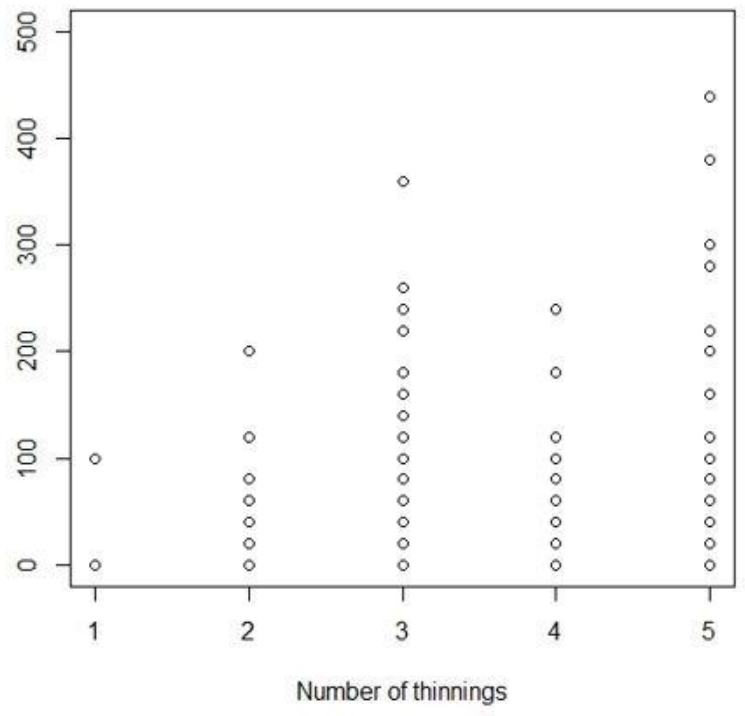

(d)

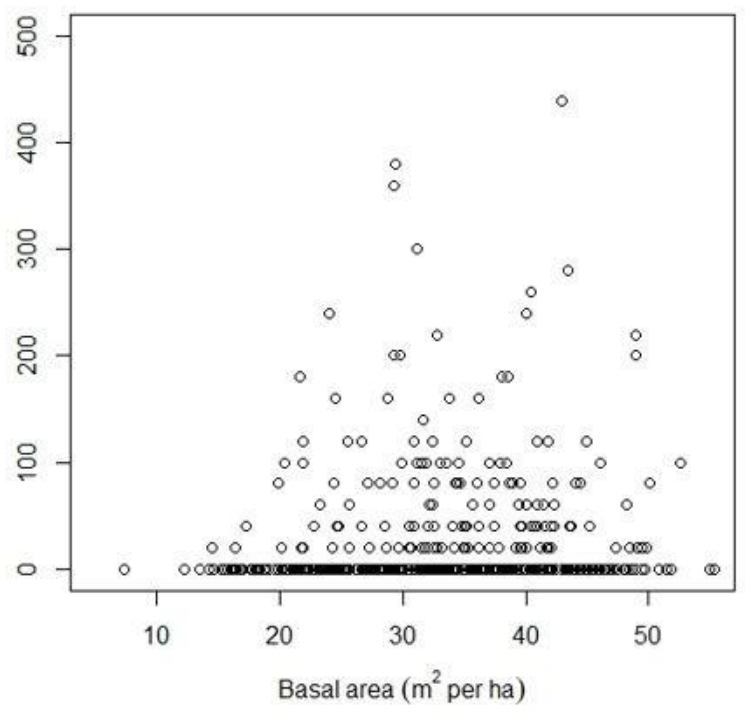

Figure 4: Number of Araucaria seedlings per ha as related to (a) the distance to the closest native secondary forest, (b) the number of thinnings, (c) the age of the pine stands and (d) the basal area of the pine stands

From Figure 4a it can be seen that the proximity to native forest fragments increased the probability of detecting Araucaria regrowth. However, it was not a guarantee since several plots close to them did not have any regrowth at all. According to the fitted model, the distance 
to native forest was negatively correlated with the number of seedlings per ha, i.e. for each distance unit ( $1 \mathrm{~m}$ ) increase, there is a reduction of $\sim 1$ Araucaria seedling.

Even though 'zero' seedlings were found all along the distances from the closest native forest fragments, it is evident that a greater number of Araucarias was detected mostly in the first $100 \mathrm{~m}$ apart from their stumps. Thus, the hypothesis is reinforced that native forest fragments act as seed sources and that seed dispersion is confined to the vicinity of mother trees.

\section{The Number of thinnings as a driving factor}

Is presented in Figure 4b. The number of Araucaria seedlings was negatively correlated with the frequency of thinnings. For each thinning that is carried out, there is a reduction of $\sim 0.6$ Araucaria seedlings ha ${ }^{-1}\left(\mathrm{Cl}_{95 \%}[0.4 ; 0.8]\right)$.

\section{Age of the pine stands as a driving factor}

It is given in Figure 4c. The age of the pine stands also plays an important role, being positively correlated. Similarly to the other factors, there was a great number of plots with no Araucaria seedlings in all covered stands of different ages. However, seedlings were observed mainly from age 14 years onwards, indicating that Araucaria regenerates preferably in older pine stands. Indeed, according to the fitted model, there was an increase of $\sim 1.1$ seedling by increasing 1 year in the age of pine stands $\left(\mathrm{Cl}_{95 \%}[1.0 ; 1.2]\right)$.

\section{Basal area of the pine stands as a driving factor}

The zero-inflated part of the fitted model presented an intercept of $\sim 6.6\left(\mathrm{Cl}_{95 \%}[1.8 ; 14.4]\right)$, this is the average absence of Araucaria seedlings in the studied area. Complementarily, basal area presented a significant negative influence (Figure 4d): the increase of one basal area unit $\left(\mathrm{m}^{2} \mathrm{ha}^{-1}\right.$ ) resulted in a decrease of $\sim 0.9$ Araucaria seedlings ha- ${ }^{-1}\left(\mathrm{Cl}_{95 \%}[0.9 ; 1.0]\right)$.

The results refer to three main aspects: ecological, nature protection and silviculture related ones which will be discussed below.

The results express not only the year in which field measurements were carried out, but several years back and, therefore, many years of seed production, dispersion and regeneration.

\section{Ecological aspects}

The main issues are the following ones:

- The results show that Araucaria is regenerating naturally under the shelter of pine plantations.

- Araucaria seed-bearing trees still do exist at many places in southern Brazil. Therefore, some natural regeneration can be counted on. Seed dispersal can be expected in a radius up to $300 \mathrm{~m}$. As a rule, however, it will be stronger in a range of $100 \mathrm{~m}$. That means that one mother tree or a small group of them is sufficient to produce regrowth for $\sim 3 \mathrm{ha}$, at least for mixtures in the succeeding stands.

It is important to note that the approach regarded in the present study was the distance to the closest native forest fragment. Although native fragments of the studied region were well preserved and obviously dominated by Araucaria trees, the fact that female seed-bearing trees were not directly at the native fragment boundary may also be one reason for the absence of regrowth close to them.

Similarly, Bittencourt \& Sebbenn (2007) found seedlings in distances up to $280 \mathrm{~m}$; $38 \%$ of them up to $60 \mathrm{~m}$ apart from the mother trees and $83 \%$ up to $160 \mathrm{~m}$. The main seed dispersers are probably birds, but possibly also squirrels.

- Loblolly pine stands offer obviously favourable conditions for the establishment and later growth of the Araucaria regrowth. First, the thick layers of needles secure a safe storage and appropriate germination prerequisites for the Araucaria seeds (Figure 5a), superior 
to sites with natural topsoil conditions and competing ground vegetation. Later on the seedlings find reasonable growing conditions under the shelter of the pines (Figure 5b and c).

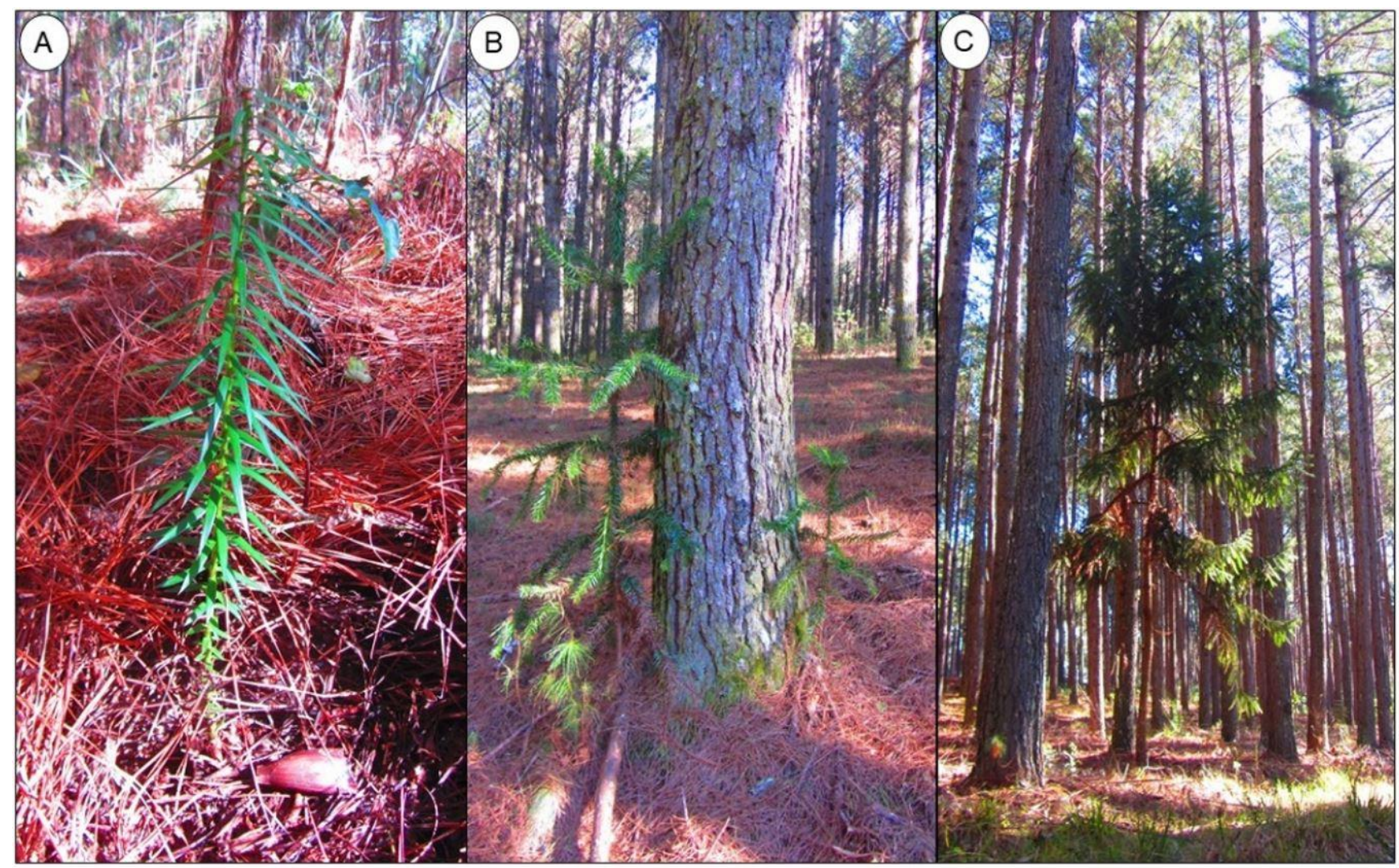

Figure 5:(A) Araucaria seedling germinated in thick pine needle layers; (B) Araucaria seedling placed near the base of a pine; $(C)$ Single young Araucaria developing satisfactorily under the shelter of a pine plantation.

These findings are confirmed by a study of Zandavalli \& Dillenburg (2015), who evaluated the effect of root competition on the establishment and growth of Araucaria seedlings in 3 site variants: in a $10 \mathrm{~m}$ high pine plantation, in grassland and in a native forest. Seedlings survival was higher in the pine stand (77\%) than in grassland (46\%) and in a native forest (43\%), where herbivores and pathogens caused losses.

Later on the pines provide a beneficial shelter for the young Araucarias, given that the pines stands are managed under relatively long production periods - as already presented. According to the findings of the present study, in average, there is one more Araucaria seedling per ha each year.

- Reduced light availability obviously does not limit the regeneration of the Araucarias. Tolerance to shading and other aspects of the species measured on the basis of photosynthetic and growth responses under different levels of irradiances indicated that Araucaria can be considered as well-adapted to moderate shading conditions (Duarte et al., 2002). However, seedlings and saplings will only become trees if there is sufficiently light (Soares, 1979; Seitz, 1986; Dillenburg et al., 2009), i.e. stands are thinned. This is contradictory to the results of the present study, where thinnings had a negative correlation with the number of Araucaria regrowth. This is probably because thinnings are currently carried out without regarding anything other than the pines itself. It is obvious that no landowner will protect or even favour Araucaria seedlings while there are legal restrictions for using it. It is quite possible that Araucaria regrowths are, therefore, being purposely damaged. 
- As young Araucaria plants have been found over distances of up to some hundred meters apart from the mother trees, birds are obviously the dominant distributors. From previous studies the azure-jay (C. caeruleus) and the pileated jay (C. chrysops) are the main dispersers. However, further and more detailed observations are necessary. Especially it has to be found out what kind of advantage the birds have by doing so.

- Plantation forestry in Brazil is an important activity comprising $\sim 8$ million ha. Although recognized by its high productivity levels $\left(>30 \mathrm{~m}^{3} \mathrm{ha}^{-1} \mathrm{yr}^{-1}\right)$ it is entirely based on monospecific and even-aged stands, planted basically with Eucalypt and Pine species (Instituto Brasileiro de Árvores, 2018), which are non-native to Brazil. These plantations are managed under high environmental, social and economic standards. Nevertheless, it is common-sense that there is a huge unused potential within the neglected native forest species - the most iconic one is Araucaria. In this context, mixed stands could be a first step in the direction to a close-to-nature silviculture regarding native species, an interesting approach regarding the long-term sustainability of land use. There is an increasing importance of close-to-nature silviculture strategies worldwide due to the numerous benefits such as delivering multiple ecosystem services compared to pure stands (Bauhus \& Schmerbeck, 2010). Furthermore, according to Liu et al. (2018), mixedspecies plantations can be more productive and have more advantages in biodiversity, economy and forest health over monocultures.

\section{Nature protection aspects}

Secondary forest remnants, woodlots, groups and single older trees are abundant. In fragments, Araucaria trees are frequently present again as the main canopy cover.

To our understanding the left-over Araucaria trees in the landscape offer great support to regenerate the species naturally.

Regarding the $\sim 1$ million ha of loblolly pine plantations in the highlands of southern Brazil (Sociedade Brasileira de Silvicultura, 2005), and the proportion of 1/3 of pine stands with some Araucaria regrowth silvicultural potential found in the present study, it suggests that $>300.000$ ha that could be managed taking into consideration the Araucaria trees; hence contributing to the conservation of the species itself and the related fauna. Comparatively, according to ABRAF (Associação Brasileira de Produtores de Florestas Plantadas, 2013), there were only 11.000 ha planted with Araucaria. Although there is no updated statistic, this area is presumably even lower at present as a result of decreasing interest due to the restrictive regulation.

Neither the older trees nor the regrowth, however, will be promoted as long as they don't have any economic value for the landowners, especially for the farmers with small properties.

\section{Silviculture related aspects}

The use of Araucaria natural regrowth may have some advantages:

- Reforestation costs are reduced, although natural regeneration is not totally free of costs as tending and early pruning may be additionally necessary.

- The range of products is widened, thus stabilising the economic performance of forest enterprises - provided there is a market for Araucaria stems and that they achieve better prices than pines which, however, will be most likely - according to former market conditions.

- The improvement of stand stability (Pretzsch et al., 2017) and the mentioned ecological advantages also improve the economic stability of the land use.

- Beyond the wood production, Araucaria regrowth could provide additional revenues due to seed collection. Trees begin to set seed between 12-15 years of age (Carvalho, 1994), with an established market of >9 million kg in 2017 (IBGE, 2018).

There are, however, some additional caveats:

- Harvesting of the pines over the Araucaria regrowth needs highly skilled forest workers and harvester operators who avoid damage of the seedlings and saplings. It may be even necessary to develop a special harvesting method. 
- Young Araucarias that stand singly or in small groups tend to grow up ramified and knotty. Thus, they must be artificially pruned. This, however, is presently not a common practice in many enterprises. Yet, it could be suitable for medium and small sized enterprises other than big companies - that they become interested in treating stands individually in later years.

It is important to note that the described additional caveats are, indeed, standard practices in many regions around the world.

We conclude that Araucaria regeneration in general appears to provide feasible silvicultural options to develop uneven-aged stand structures, at least in 1/3 of the pine stands, provided that these are sufficiently thinned, avoiding damages to Araucaria regrowth, and kept for longer than the conventional rotation periods. As the Araucaria regrowth is normally distributed heterogeneously, it seems to be advisable to segment the pine stands or parts of them into 3 classes according to the existence of Araucaria seedlings or saplings as shown in Table 2.

Table 2: Classifying of density of Araucaria seedlings and their silvicultural value

\begin{tabular}{|c|c|c|c|}
\hline Class & $\begin{array}{l}\text { DISTANCE } \\
\text { BETWEEN } \\
\text { YOUNG } \\
\text { ARAUCARIAS } \mathrm{m}\end{array}$ & Silvicultural Value & $\begin{array}{l}\text { Potential silvicultural approaches to } \\
\text { improve growing conditions }\end{array}$ \\
\hline I & $\leq 10$ & $\begin{array}{l}\text { Sufficient for succession of } \\
\text { pure Araucaria stands. }\end{array}$ & $\begin{array}{c}\text { Opening of canopy of pines to improve } \\
\text { growing condition for young Araucarias } \\
+ \text { pruning. }\end{array}$ \\
\hline II & $10-50$ & $\begin{array}{l}\text { Sufficient for use of } \\
\text { Araucaria as a mixture tree. }\end{array}$ & $\begin{array}{l}\text { Groupwise improvement of growth } \\
\text { conditions for Araucaria + pruning. }\end{array}$ \\
\hline III & $>50$ & $\begin{array}{l}\text { Negligible; only } \\
\text { exceptionally suitable as } \\
\text { future seed tree. }\end{array}$ & $\begin{array}{l}\text { None; exceptionally gapwise opening of } \\
\text { pine canopy. }\end{array}$ \\
\hline
\end{tabular}

However, in case advantage could be taken of the Araucaria regeneration in order to establish mixtures, the ordinary pine plantation management will need several essential and far-reaching alterations:

- The conventional rotation periods are too short, as the Araucaria seedlings tend to appear hesitantly and grow slowly under closed pine canopies at the beginning. At pulpwood rotations of 12-15 years they have little chance to develop and to function as mixture trees or form the next stand generation. Therefore, it will be advisable to prolong the production period to 30-40 years, which, although confined, is already regarded as management strategy by some independent log producers in southern Brazil.

- Early and heavy thinning are necessary to early start improving the light conditions for the young Araucarias.

- The common clear-cut system has to be abandoned as the Araucaria saplings can't be sufficiently protected while the timber crop is harvested and extracted. Therefore, the Araucarias have to be gradually released from overtopping and subsequently older pines must be carefully extracted in form of shelter-wood cuttings, preferably by harvesters to reduce damages.

The consideration of Araucaria as a mixture tree species seems to be imperative as pure loblolly pine plantations exist in the magnitude order of more than a million hectares and are threatened by the risk of disseminating pests or abiotic perils like fires that may cause disastrous environmental and economic collapses. To diminish the apparent hazards of pine plantations, indigenous species should be reintroduced, at least as mixture trees.

We imply that the site conditions at the enterprise where the studies took place are representative for large areas of the southern Brazilian highlands with regard to climate, soils and topography as well as for the growth of young Araucarias. Moreover, we guess that they 
can be used for forest management in future. Thus, the results are suitable to provide indications for future treatments of larger proportions of the loblolly pine plantations.

\section{Final considerations}

For implementation into practice two main preconditions are indispensable:

- First, it will be necessary to revise the restrictions as caused by the nature conservancy laws. In them, obviously, nature conservation aspects are much valued, whereas the great advantages of mixtures between exotic and indigenous tree species in view of reducing the ecological and economic risks are not sufficiently considered.

As long as landowners and foresters will not be permitted to naturally regenerate, grow and finally harvest Araucaria stems they will not be motivated in taking care of and managing them - following the deeper insight: 'What cannot be used, will not be protected'. It may even become a political issue to encourage landowners to invest into a species that will provide advantage in the future; otherwise they will not take any interest in it at all.

- Secondly, landowners need to be convinced that it makes sense for them to convert their management system from predominantly pulpwood to quality timber production with longer rotation periods and the abandonment of large-scale clear-cuts. This may be especially reasonable for farmers and landowners of small properties. They, of course, need training how Araucaria could and should be managed for their economic benefit. The provision of financial subsidies by the state or regional boards could significantly help to encourage Araucaria establishment and later thinnings as well as pruning.

From the scientific point of view, research seems to be necessary to find out which animal (possibly only bird) is the main distributor and what advantaged does it take from spreading and burying the seeds in the needle litter of the pines.

\section{CONCLUSIONS}

In general, the results are encouraging to use the natural regenerated regrowth of Araucaria in order to increase the occurrence of this species in its former distribution area and to give it an opportunity to become an important mixture tree species in pine plantation regions.

Araucaria is definitely the first choice for the highlands in southern Brazil - mainly because of ecological considerations. But apart from the more ecologically related aspects they offer promising economic development potentialities for landowners and forest enterprises. However, profound changes of the common pine plantation management rules are necessary.

\section{REFERENCES}

Adan, N., Atchison, J., Reis, M. S., \& Peroni, N. (2016). Local Knowledge, use and management of ethnovarieties of Araucaria angustifolia (Bert.) Ktze. in the Plateau of Santa Catarina, Brazil. Economic Botany, 70(4), 353-364. http://dx.doi.org/10.1007/s12231-016-9361-z.

Anjos, L., \& Shibatta, O. A. (2010). On the habitat occupancy of some neotropical jays in South America, genus Cyanocorax. Semina. Ciências Biológicas e da Saúde, 31(2), 153-158. http://dx.doi.org/10.5433/1679-0359.2011v32n2p153.

Associação Brasileira de Produtores de Florestas Plantadas - ABRAF. (2013). Anuário estatístico, ano base 2012 (142 p.). Brasília: ABRAF.

Bauhus, J., \& Schmerbeck, J. (2010). Silvicultural options to enhance and use forest plantation biodiversity. In J. Bauhus, P. V. Der Meer \& M. Kanninen (Eds.), Ecossystem goods and services from plantation forest (276 p.). Bogor: CIFOR.

Beaujean, A. A., \& Morgan, G. B. (2016). Tutorial on using regression models with count outcomes using R. Practical Assessment, Research \& Evaluation, 21(2), 1-19.

Bittencourt, J. V. M., \& Sebbenn, A. M. (2007). Patterns of pollen and seed dispersal in a small, fragmented population of the wind-pollinated tree Araucaria angustifolia in southern Brazil. Heredity, 99(6), 580-591. PMid:17928810. http://dx.doi.org/10.1038/sj.hdy.6801019. 
Bordignon, M., \& Monteiro-Filho, E. L. A. (2000). The squirrel Siurus ingrami (Sciuridae: Rodentia) as disperser of Araucaria angustifolia seeds (Araucariaceae: Pinophyta). Arquivos de Ciências Veterinárias e Zoologia da UNIPAR, 3(2), 139-144.

Brasil. (2001). Resolução Conama $n^{\circ} 278$, de 24 de maio de 2001. Dispõe sobre o corte e a exploração de espécies ameaçadas de extinção da flora da Mata Atlântica. Diário Oficial [da] República Federativa do Brasil, Brasília.

Brasil. (2006). Lei n 11.428, de 22 de dezembro de 2006. Dispõe sobre a utilização e proteção da vegetação nativa do Bioma Mata Atlântica, e dá outras providências. Diário Oficial [da] República Federativa do Brasil, Brasília.

Brum, F. T., Duarte, L. D., \& Hartz, S. (2010). Seed removal patterns by vertebrates in different successional stages of Araucaria forest advancing over southern Brazilian grasslands. Community Ecology, 11(1), 35-40. http://dx.doi.org/10.1556/ComEc.11.2010.1.6.

Carvalho, P. E. R. (1994). Espécies florestais brasileiras: recomendações silviculturais, potencialidades e uso da madeira. Colombo: CNPF/EMBRAPA.

Dillenburg, L., Franco, A. M. S., Coutinho, A. L., Körndorfer, C. L., Clebsch, C. C., Duarte, L. S., Ferla, L., Rosa, L. M. G., Silva, L. G. R., Garbin, M. L., Mósena, M., \& Zandavalli, R. B., \& Yamasaki, S. (2009). Aspectos ecofisiológicos da regeneração de Araucaria angustifolia. In C. R. Fonseca, A. F. Souza, A. M. Leal-Zanchet, T. Dutra, A. Backes \& G. Ganado (Eds.), Floresta com araucária: ecologia, conservação e desenvolvimento sustentável (pp. 57-65). Ribeirão Preto: Holos.

Dortzbach, D., Pereira, M. G., Anjos, L. H. C., Fontana, A., \& Silva Neto, E. C. (2016). Genesis and classification of soils from subtropical mountain regions of southern Brazil. Revista Brasileira de Ciência do Solo, 40(0), 1-15. http://dx.doi.org/10.1590/18069657rbcs20150503.

Duarte, L. S., Dillenburg, L. R., \& Rosa, L. M. G. (2002). Assessing the role of light availability in the regeneration of Araucaria angustifolia (Araucariaceae). Australian Journal of Botany, 50(6), 741-751. http://dx.doi.org/10.1071/BT02027.

Ganade, G., Miriti, M. N., Mazzochini, G. G., \& Paz, C. P. (2011). Pioneer effects on exotic and native tree colonizers: insights for Araucaria forest restoration. Basic and Applied Ecology, 12(8), 733-742. http://dx.doi.org/10.1016/j.baae.2011.09.011.

Instituto Brasileiro de Árvores - IBÁ. (2018). Relatório 2017 (80p.). Brasília: IBÁ.

Instituto Brasileiro de Geografia e Estatística - IBGE. (2018). Produção da extração vegetal e silvicultura. Rio de Janeiro: IBGE.

Iob, G., \& Vieira, E. M. (2008). Seed predation of Araucaria angustifolia (Araucariaceae) in the Brazilian Araucaria Forest: influence of deposition site and comparative role of small and 'large' mammals. Plant Ecology, 198(2), 185-196. http://dx.doi.org/10.1007/s11258-007-9394-6.

IUCN Red List of Threatened Species. (2017). Red list: version 2017-1. Retrieved in 2017, July 4, from www.iucnredlist.org

Lima, A. R., \& Capobianco, J. P. R. (1997). Mata Atlântica: avanços legais e institucionais para sua conservação (No. 004, Documentos do ISA). Brasília: Instituto Sócio Ambiental.

Liu, C. L. C., Kuchma, O., \& Krutovsky, K. V. (2018). Mixed-species versus monocultures in plantation forestry: development, benefits, ecosystem servicesand perspectives for the future. Global Ecology and Conservation, 15, e00419. https://doi.org/10.1016/j.gecco.2018.e00419.

Mantovani, A., Morellato, L. P. C., \& Reis, M. S. D. (2004). Reproductive phenology and seed production of Araucaria angustifolia (Bert.) O. Kuntze. Brazilian Journal of Botany, 27, 787-796.

Overbeck, G. E., Mueller, S. C., Fidelis, A., Pfadenhauer, J., Pillar, V. D., Blanco, C. C., Boldrini, I. I., Both, R., \& Forneck, E. D. (2007). Brazil's neglected biome: the South Brazilian Campos. Perspectives in Plant Ecology, Evolution and Systematics, 9(2), 101-116.

Pereira, F., \& Ganade, G. (2008). Spread of a Brazilian keystone-species in a landscape mosaic. Forest Ecology and Management, 255(5-6), 1674-1683. http://dx.doi.org/10.1016/j.foreco.2007.11.026.

Pretzsch, H., Forrester, D. I., \& Bauhus, J. (2017). Mixed-species Forests: ecology and management (653 p.). USA: Springer. http://dx.doi.org/10.1007/978-3-662-54553-9.

QGIS Development Team. (2017). QGIS Geographic Information System. Open Source Geospatial Foundation Project. Retrieved in 2017, July 4, from http://qgis.osgeo.org

R Core Team. (2017). R: a language and environment for statistical computing. Vienna, Austria: R Foundation for Statistical Computing. Retrieved in 2017, July 4, from https://www.R-project.org/

Reis, M. S., Ladio, A., \& Peroni, N. (2014). Landscapes with Araucaria in South America: evidence for a cultural dimension. Ecology and Society, 19(2), 43. http://dx.doi.org/10.5751/ES-06163-190243. 
Schüssler, G. (2014). Conservação pelo uso de Araucaria angustifólia (Bertol.) Kuntze: análise de aspectos produtivos do pinhão e de interações com a fauna em diferentes fitorregiões do sul do Brasil [Tese de doutorado]. Universidade Federal de Santa Catarina, Florianópolis.

Seitz, R. (1986). Erste Hinweise für die waldbauliche Behandlung von Araukarienplantagenwäldern. Annales des Sciences forestieres, 43(3), 327-338.

Soares, R. V. (1979). Considerações sobre a regeneração natural de Araucaria angustifolia. Revista Floresta, 10(2), 12-18.

Sociedade Brasileira de Silvicultura - SBS. (2005). Estatísticas. São Paulo: SBS.

Vibrans, A. C., Mcroberts, R. E., Lingner, D. V., Nicoletti, A. L., \& Moser, P. (2012). Original and present forest cover in Santa Catarina. In A. C. Vibrans, L. Sevegnani, A. L. Gasper \& D. V. Lingner (Eds.), Diversidade e conservação dos remanescentes florestais. Inventário florístico florestal de Santa Catarina (Vol. 1, pp. 65-76). Blumenau: Editora da FURB.

Vibrans, A. C., Mcroberts, R. E., Moser, P., \& Nicoletti, A. L. (2013). Using satellite image-based maps and ground inventory data to estimate the area of the remaining Atlantic forest in the Brazilian state of Santa Catarina. Remote Sensing of Environment, 130, 87-95. http://dx.doi.org/10.1016/j.rse.2012.10.023.

Vieira, E. M., \& lob, G. (2009). Dispersão e predação de sementes de Araucaria angustifolia. In C. R. Fonseca, A. F. Souza, A. M. Leal-Zanchet, T. Dutra, A. Backes \& G. Ganado (Eds.), Floresta com araucária: ecologia, conservação e desenvolvimento sustentável (pp. 57-65). Ribeirão Preto: Holos.

Zandavalli, R. B., \& Dillenburg, L. R. (2015). Response of Araucaria angustifolia seedlings to root competition in three different plant communities of southern Brazil. New Zealand Journal of Botany, 53(3), 139-154. http://dx.doi.org/10.1080/0028825X.2015.1043922.

Author's contributions: JH: conceptualization, methodology, supervision, writing; MDJ: conceptualization, data curation, formal analysis, methodology, writing; CAP: formal analysis, writing; AC: formal analysis, writing; AS: methodology, writing. 